\title{
REPRESIVITAS NEGARA TERHADAP KOMUNITI BANGSA
}

\author{
Oleh: Yusdani*
}

Abstract

The article below tries to trace the roots of state violence toward the communities in Indonesia. The case of Act No. 5 year 1979 regarding the Community (desa, marga, nagari and so on). Government denotes an example of State dominant intervention to communities. This policy bas emerged the negative impacts, for instance destructing creative social energy of society, contradicting to self government, and contrary to democracy and the justice principles. The policy of state to regulate and unify the form of community government could be called a kind of the state terrorism. Hence, it is urgent to deconstruct, reconstruct and criticizes the possibilities state re-regulate the similar cases in reformation era nowadays eitber by accident or by design.

هاول الكاتب إبرازصياغة نظام السياسة والملكومة. في إنلونيسيا، وإيراز البنية لمحتبع الإندونيسى

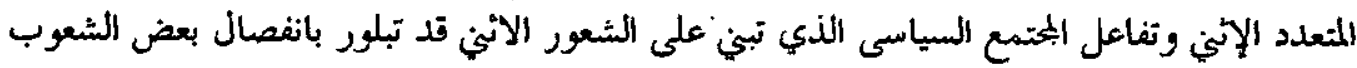
فلرالية إنلدونيسيا كدولة مستقلة ومن بعض جيوانب نظام إندونيسيا. فإن مصلحة هذه البلدة قد

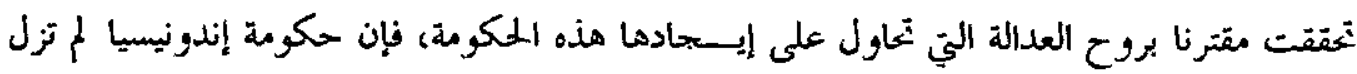
ترى حركة الانفصال في عدة مناطق مَدد الأمن والاستقرار للدولة.

Keywords: intervensi, komuniti, negara, desa dan otonomi.

* Dosen dan Peneliti pada Pusat Studi Islam Universitas Islam Indonesia Yogyakarta E-mail: yusdani_msi@yahoo.com 


\section{A.Pendahuluan}

Ketika Sumpah Pemuda 1928 diikratkan dengan menyatakan kesatuan bangsa, kesatuan bahasa dan kesatuan Tanah Air Indonesia, kemudian melalui perjuangan Kemerdekaan 1945 dikukuhkan dalam wadah Negara Kesatuan Republik Indonesia, sebenarnya telah menegaskan tujuan diselenggarakannya negara, yaitu mewujudkan keadilan dan kemakmuran bagi seluruh rakyat Indonesia, sebagaimana termaktub dalam pernbukaan UUD 1945. Komitmen politik untuk keadilan dan kemakmuran seluruh rakyat Indonesia adalah komitmen fundamental Negara Kesatuan Republik Indonesia (NKR) yang tidak dapat ditawar. Ini berarti, NKRI tanpa keadilan dan kemakmuran seluruh rakyat adalah NKRI yang dusta, karena tidak sesuai dengan hakikat dan tujuan didirikannya NKRI. ${ }^{1}$

Oleh karena itu, jika menyimak kembali munculnya perlawanan dan penentangan atas NKRI, kita mestinya menyadari, sebenatnya semua bentuk perlawanan itu disebabkan oleh tealitas kehidupan masyarakat kita sendiri, yang mencerminkan adanya ketidakadilan dan ketidakmakmuran yang makin meluas. Kemudian dimanipulasi tendensi politik kekuasaan yang kuat, dengan memanfaatkan suasana tumpang tindihnya berbagai persoalan yang komplek, baik kekecewaan pribadi, kepentingan ekonomi, yang diramu konflik sosial, aliran politik, dan paham keagamaan. ${ }^{2}$

Jika NKRI terus dirundung ketidakadilan, kemiskinan, dan kebodohan, tanpa kepastian jalan keluarnya, dapat dipastikan akan muncul pertanyaan kritis generasi muda bangsa, apakah ada manfaatnya ber-NKRI? Jika satuan pulau-pulau yang berjajar dari Sabang sampai Merauke yang kaya raya oleh kandungan alam, mengapa setelah kekayaan itu disatukan pengelolaannya dalam NKRI, hanya menghasilkan kemiskinan dan ketidakadilan?? ? $^{3}$ Dalam hubungan ini, termasuk juga persoalan munculnya fenomena ethno-nationalism dan sentimen anti negara di Indonesia yang kadangkadang mengemuka, seperti dikemukakan oleh Aliansi Masyarakat Adat Nusantara (AMAN) dalam kongresnya di Jakarta pada bulan Maret 1999 menyatakan “ Kami tidak akan mengakui negara, kalau negara tidak mengakui kami”. Inti tuntutan ini adalah agat negara memberikan pengakuan terhadap masyarakat adat sebagai masyarakat berdaulat yang berhak memerintah diri mereka sendiri dan sumber-sumber daya yang menjadi andalan hidup mereka. ${ }^{4}$

'Musa Asy'arie (2005), NKRI, Budaja Politik dan Pendidikan, Yogyakarta: LESFI, p. 3.

${ }^{2}$ Ibid., pp. 3-4.

${ }^{3}$ Buktinya negara dililit utang besar yang mencapai lebih 150 miliar dollar AS, bahkan untuk memenuhi kebutuhan panganpun, kita masih tergantung impor. Kehidupan ekonomi Indonesia masih tergantung luar negeri, baik modal, teknologi, maupun sumber daya manusia, karena kualitas sumber daya manusia Indonesia makin merosot, berada pada peringkat 112 di antara 175 negara dunia dan di bawah Vietnam yang ada di peringkat 110. Musa Asy'arie, ibid., p. 5.

"Tania Murray Li (2005), "Masyarakat Adat dan Masatah Pengakuan" dalam Noer Fauzi (peny.), 
Dasat tuntutan di atas adalah bahwa mereka sudah ada sebagai masyarakat yang organisasi sosialnya khas, memiliki kedaulatan atas kehidupan mereka sendiri dan wilayah di mana mereka hidup jauh sebelum negara Indonesia terbentuk. Sebagai dasar argumentasi yang dikemukakan Aliansi Masyarakat Adat Nusantara adalah bahwa masyarakar adat memiliki budaya yang khas, mengetahui batas sosial antara siapa yang menjadi anggota mereka dan siapa yang tidak, dan memiliki tata pemerintahan sendiri, merupakan bentuk masyarakat sosial asli di Indonesia. ${ }^{5}$

Tatanan sistem masyarakat adat di atas mengalami problema serius karena dampak dari kebijakan pemerintahan yang tepresif. Salah satu contohnya adalah adanya birokratisasi komuniti (desa). Birokratisasi desa ${ }^{6}$ dalam sistem Pemerintahan Nasional di Republik Indonesia, melalui pemberlakuan Undang-Undang No. 5 Tahun 1979 tentang Pemerintahan Desa (selanjutnya disebut UUPD No. 5 Tahun 1979), telah menimbulkan dampak negatif yang tidak kecil. Dalam strategi birokratisasi desa ini, meski otonomi desa, juga disinggung-singgung setidaknya pasal 18 UUD 1945 juga menjadi konsideran UUPD No. 5 Tahun 1979, desa tidak hanya dirubah statusnya, yaitu dari "masyarakat hukum" menjadi "sekumpulan orang yang tinggal bersama..." melainkan juga di dalamnya dicangkokkan sebuah institusi baru, yaitu apa yang disebut sebagai Pemerintahan Desa. ${ }^{8}$

Bersamaan dengan itu governance sistem (sistem pengolahan hidup bersama) yang ada dalam desa, yang di dalamnya tercakup government sistem (sistem Pemerintahan), digantikan oleh suatu sistem Pemerintahan Desa yang baru, yang sama sekali berbeda dan karenanya asing bagi warga desa. Padahal, sejatinya, ada perbedaan "rasa keadilan" yang amat besar antara desa sebagai suatu" persekutuan sosial" dengan desa sebagai suatu "satuan administtasi pemerintahan". Ada "tasa keadilan" yang hidup dalam desa yang tidak tettampung dalam desa sebagai "satuan administratif pemerintahan". Demikian pula aturan-aturan yang ada dalam ketentuan administratif pemerintahan desa itu tidak sesuai dengan "tasa keadilan" masyarakat

\footnotetext{
Gerakan-gerakan Rakyat Dunia Ketiga, Yogyakarta: Resist Book, pp. 277-278.

${ }^{5}$ Ibid., p. 278.

${ }^{6} \mathrm{Kata}$ 'desd' dalam kalimat ini dengan sengaja dicetak miring. Hal ini dipetlukan untuk membedakan desa sebagaimana yang dimaksudkan oleh UUPD No.5/1979 (dalam dokumen ini dicetak biasa) dengan desa (dengan cetak miring) sebagai suatu organisasi sosial sebagaimana yang dipahami dan dikonsepsikan oleh warga persekutuan sosial yang bersangkutan. Penyebutan desa dalam dokumen ini dapat juga berarti dan dipertukarkan dengan nagari (di Minangkabau), marga (di Palembang), dan lain sebagainya.

${ }^{7}$ Lembaran Negara tahun 1979 No. 56, Tambahan Lembaran Negara No. 3153.

${ }^{8}$ R. Yando Zakaria (2002), "Pemulihan Kehidupan Desa dan UU No. 22 Tahun 1999" dalam UNISLA Jurna/Imu-IImu Sosid/No. 46/XXV/III/2002, Yogyakarta: Universitas Islam Indonesia, p. 280; R.Yando Zakaria (2004), Merebut Negara Beberapa Catatan Reflektif tentang Upaja-upaya Pengakuan, Pengembalian dan Pemzuliban Otonomi Desa, Yogyakarta: Lapera Pustaka Utama Bekerja sama dengan Karsa, pp. 15-16.
} 
desa yang umum betlaka. Desa yang semula hidup atas dasar sentimen paguyupan, misalnya diubah menjadi suatu institusi yang katanya "rasional". Dengan pemberlakuan UU No. 5 Tahun 1979, desa, atau yang disebut lain di wilayah kebudayaan lainnya, dipecah dan atau digabung satu sama lainnya, untuk menjadi sebuah" desa gaya baru".?

Proses yang menggunakan strategi transplantasi di atas meminjam istilah Soetandjo Wignjosoebtoto, ${ }^{10}$ telah menimbulkan dampak negatif yang tidak kecil. Termasuk menghancurkan energi sosial kreatif ${ }^{11}$ yang sejatinya diperlukan sebagai modal dasar bagi berdirinya negara dan bangsa Indonesia. ${ }^{12}$ Sejauh ini, masalah modernisasi desa - telah dan akan menjadi salah satu titik tolak bagi berkembangnya sentimen anti negara ( sekaligus juga bangsa) dan mendorong munculnya kesadaran politik di tingkat suku bangsa (ethno-nationalism) yang mengancam integrasi negara yang terus meningkat intensitasnya dalam beberapa tahun belakangan ini. Di masamasa yang akan datang, jika pesoalan ini tidak dapat dicarikan solusinya secara tepat dan cepat, bukan tidak mungkin sentimen anti negara dan ethno-nationalism itu akan makin membesar lagi: Hanya saja jika ini terjadi dalam situasi konsep negata adalah sesuatu yang sakral, disintegrasi itu tentunya akan disertai chaos yang menuntut korban nyawa, rasa perikemanusiaan, dan harta benda. Hal yang demikian itulah yang sama sekali tidak diinginkan. ${ }^{13}$

${ }^{2}$ Pandangan berbagai pihak lihat R Yando Zakatia (2000), Abieb Tandeh, Masyarakat Desa di Bawah Orde Barm, Jakarta: Lembaga Studi dan Advokasi Masyarakat, p. 12.

${ }^{10}$ Soetandjo Wignjosoebroto (1997), "Komunitas Lokal Versus Negara Bangsa: Perbedaan Persepsi dan Konsepsi tentang Makna Lingkungan", makalah yang dipresentasikan dalam diskusi bertemakan "Hubungan Negara - Masyarakat dalam Pengelolaan Lingkungan" yang diselenggatakan oleh Yayasan Lembaga Bantuan Hukum Indonesia, Jakarta: tanggal 3 Juli 1997.

${ }^{11}$ Uphoff (1996), Learning From Gai Oya, Possibilities for Participatory Development and Post Newtomian Social Science, London: Intermediate Technology Publications Ltd., p. 34.

${ }^{12}$ Dalam sebuah Seminar Nasional yang diselenggarakan oleh Lembaga Ilmu Pengetahuan Indonesia (LIPI), Prof. Dt. Taufik Abdullah, sejarawan ini secara meyakinkan mengatakan bahwa pemberlakuan UU No. 5/1979, yang telah menimbulkan dampak negatif yang tidak terhingga itu, merupakan salah satu kesalahan sejarah Nasional terbesar yang pernah terjadi selama ini.

${ }^{13} \mathrm{R}$ Yando Zakatia, op. ait., tentu saja tidak petiu menangisi jika disintegrasi itu benat-benar terwujud (lihat pasdangan penulis ini tentang hal ini pada bagian penutup). tentang pemerintahan daerah desa dalam sistem administrasi pemerintahan nasional telah dikernbalikan "statusnya" sebagaimana mestinya pada bab I, ketentauan umum, pasal I, butir o. Antara lain dinyatakan bahwa "desa atau yang disebut dengan nama lain, selanjutnya disebut desa adalah kesatuan masyarakat hukum yang memiliki kewenangan untuk mengatur dan mengurus kepentingan masyarakat setempat berdasarkan asal usul dan adat istiadat setempat yang diakui dalam sistem pemerintahan nasional...". Sebelumnya dalam UU No. 5 Tahun 1979, desa didefinisikan sebagai "suatu wilayah yang ditempati oleh sejumlah penduduk sebagai kesatuan masyarakat termasuk di dalamnya kesatuan masyarakat hukum yang mempunyai otganisasi pemerintahan terendah langsung di bawah camat..." (pasal I butir a). Yang menarik dalam bagian menimbang, butir e. UU No. 22 Tahun 1999 dikatakan "bahwa Undang-undang No. 5 Tahun 1979 


\section{B. Negara dan Komunitit ${ }^{7 t}$}

Masalah-masalah mendasar di atas sudah selayaknya menjadi salah satu agenda reformasi yang tengah bergulir sejak tumbangnya rezim Orde Baru di pertengahan tahun 1998 yang lalu. Sesuai dengan semangat pasal 18 UUD 1945, berbeda dengan UU No. 5 Takun 1979, melalui pemberlakuan UU No. 22 Tahun 1999, kemudian diubah dengan UU No.32 Tahun 2004 tentang pemerintahan daerah. Akan tetapi pertanyaan yang muncul dalam kaitan ini adalah apakah ketentuan-ketentuan yang mengangkut desa dan pemerintahan desa sebagaimana yang terkandung pada UU No. 22 Tahun 1999 tentang pemetintahan daetah, kemudian diubah dengan UU No. 32 Tahun 2004 tentang pemerintah daetah memang telah memaknai dan memperlakukan desa sebagaimana mestinya, sehingga mampu memulihkan dampak yang telah diderita desa selama ini? Lebih jauh dapat pula diungkap pertanyaan lain: Apakah penataan ulang hubungan antara negara dan komuniti tersebut, telah menjamin terciptanya kondisi yang memungkinkan bagi terus berlangsungnya upaya penciptaan negara-bangsa (nation state) Indonesia di masa-masa yang akan datang?

“...Tidak ada partisipasi atau mobilisasi rakyat secara tetap, yang ada adalab bentuk partisipasi yang secara tetap melibatkan begitu banyak warga negara sehubungan dengan pelaksanaan kebijakan nasional dan bukan pembuatan kebijakan itu....'Demikian salab satu cin sistem pemerintahan di Indonesia, yang oleb Jackson didefinisikan sebagai suatu sistem pemerintaban birokratis. Lebib jaub dikatakannya pula bahwa partisipasi lokal cenderung diatur leswat otoritas tradisional dan pengelompokan patron-klien dan

tentang pemerintahan di desa (Lembaran Negara tahun 1979 No. 56, Tambahan lembaran negara No. 3153) yang menyeragamkan nama, bentuk, susunan, dan kedudukan pemerintahan desa tidak sesuai dengan jiwa Undang-undang dasar 1945 dan perlunya mengakui setta menghormati hak asal usul daerah yang bersifat istimewa sehingga perlu diganti"'. Suatu keputusan politik yang tepat dan aspiratif, meski terasa agak terlambat dan diperhalus maknanya. Barangkali, baru kali inilah ada sebuah Undang-Undang di sebuah negara yang dinyatakan oleh undang-undangnya yang lain sebagai undang-undang yang tidak sesuai dengan konstitusi negara.

${ }^{14}$ Kata komumiti (bukan rakyat atau masyarakat) sengaja digunakan dalam bagian ini, untuk menghindarkan diri dari pemaknaan yang nettal dan longgar dari dua kata yang disebut terakhir. Adapun yang dimaksud dengan kommiti dalam tulisan ini adalah menunjuk pada satuan hidup masyarakat setempat yang khas, dengan suatu identitas dan solidaritas yang telah terbentuk dari dalam dan berkembang dalam waktu yang lama. Sedangkan komtnitas dipakai guna mengacu pada kelompok di dalam masyarakat yang tetbentuk dati atas, sehingga identitas dan solidaritas antarpenduduknya masih lemah, Koentjaraningrat (1990), Sejarab Teori_Antropologi II, Jakarta: UI Press, p. 135. Dalam buku Koentjaraningrat yang terbit lebih awal, community didefinisikannya sebagai kesatuan hidup manusia, yang menempati suatu wilayah yang nyata, dan betinteraksi menurut suatu sistem adat-istiadat, serta yang terikat oleh suatu rasa identitas komuniti, Koentjaraningrat (1979), Pengantar Imu Antropologi, Jakarta: Aksara Baru, p. 162. Dengan demikian, dalam pembahasan ini, twatga negara tidak hanya diacu ke dalam kategorikategori yang netral dan longgat itu, tetapi secara khusus diacu dalam kategori ikatan-ikatan sosial dan kultural yang khusus. Dengan cara demikian, pembicaraan tentang ketegangan antara negara dan konstituennya menjadi lebih tajam. 
bukan lewat kelompok yang berdasarkan pada atribut sosial yang sama, misalnya kelas. Selain itu, mobilisasi penduduk yang efektif hanya ditujukan untuk langkablangkab jangka pendek, seperti pemiliban umum dan demonstrasi. Keterbatasan utama pemerintaban adalah ketidakmampuannya untuk memobilisasi rakyat yang berkorban demi program-program nasional tertentu dan untuk mencapai target-target yang memerlukan partisipasi yang benar-benar sukarela dari rakyat secara keseluruban. ${ }^{15}$

Dengan demikian, terdapat jurang yang memisahkan pemerintah di satu pihak dengan takyat di pihak lain. Sehingga, sudah sejak lama para ahli memikirkan bagaimana jurang ini dapat dijembatani dan dengan jalan apa rakyat dapat dibujuk untuk ikut terlibat (dalam berbagai kegiatan bernegara). ${ }^{16}$ Jurang pemisah antara "sektor" pemerintah dan rakyat ini diwamai - meminjam istilah yang digunakan Bijlmer dan Reurink, ketegangan. Ini muncul sebagai akibat adanya perbedaanperbedaan antara apa yang disebut Bijlmer dan Reurink, ketegangan ini muncul sebagai norma lokal di satu pihak dan norma pemerintah di pihak lain. Norma lokal mengacu pada konsepsi-konsepsi masyarakat dalam melihat berbagai hal, termasuk kebijakan pemerintah dan kebutuhan-kebutuhan hidupnya sendiri sebagaimana yang mereka lihat. Menurut pendapat rakyat setempat, lingkungan atau kampung memiliki arti konktet. Harapan dan kepentingan mereka juga konkret di pihak lain, norma pemerintah juga mengacu pada hal yang sama, hanya saja sebagaimana dirumuskan sendiri oleh pihak pemerintah itu. ${ }^{17}$

Dalam konteks ini, Ufford menulis:

“...Sebagai penvakilan dari tingkat organisasi yang lebih tinggi, kepala desa, tenaga kerja lapangan dan pegawai kantor Agama setempat (dan- lembaga-lembaga yang Lain terkait pada sistem organisasi pemerintahan di tingkat desa). Menghadapi banyak tuntutan dari atasan mereka yang harus dipenubi. 'Kedudukan mereka sendiri adalab kurang lebih suatu program pemerintahan juga. Peranan resmi mereka menampilkan sikap dari penguasa pusat. Sebagai kepala desa, mereka adalab pejabat nasional yang ditempatkan di daerab. Setiap orang mengetabui tugas resmi dari pegawai administrasi dalam memelibara bukum dan ketertiban, dan metujiudkan pembangunan dalam sejumlab program dan proyek":'

UUPD No. 5 atau 1979 memang telah mengubah total wajah desa jika

${ }^{15}$ Dikutip dari Joep Bijlmer \& Martin Reutink (1988), "Kepemimpinana Lokal di Lingkungan Urban Jawa: dari Ideologi ke Realitas" dalam Philip Quartes van Ufford (ed.), Kepemimpinan Lokal dan Implementasi Program, Jakarta: PT. Gramedia, p. 151. Melalui penelitian-penelitian mereka pada komunitikomuniti urban di Semarang dan Surabaya, Joep Bijlmer \& Martin Reurink, Ibid. p. 168, mendukung tesis-tesis yang dikemukakan Jackson tersebut.

${ }^{16}$ Bijlmer \& Reurink, Ibid., p. 168.

${ }^{17}$ Ibid., khususnya pp. 159-163.

${ }^{18}$ Ufford, op. cit., pp. ix. 
dibandingkan dengan masa-masa sebelumnya, ${ }^{19}$ dan perubahan itu bukanlah suatu perubahan yang tidak direncanakan (by accident) melainkan suatu perubahan yang memang ditencanakan sedemikian tupa (by design), melalui suatu perdebatan politik di antara kekuatan-kekuatan politik yang tidak berimbang di bawah bayang-bayang etika politik yang didominasi oleh kekuatan rezim "Orde Baru" yang jauh dari setnangat demokratisasi. ${ }^{20}$ Meski begitu tentu akan terkesan naïf dan tidak adil jika dikatakan bahwa "kasus UUPD No. 5 atau 1979" sebagai satu-satunya peristiwa, yang terjadi begitu saja dari ketegangan antara negara dan desa (komuniti) sepanjang sejarahnya. Pengamatan Jackson sendiri telah dilakukan jauh sebelum UUPD No. 5 atau 1979 diundangkan dan diberlakukan di seluruh negeri. Namun mengacu pada hasil pengamatan Biljmer dan Reurink (1998), ${ }^{21}$ Jatiman (1995), ${ }^{22}$ Zakariya (2000), ${ }^{23}$ dan Syafitri (2001), ${ }^{24}$ sekedar menyebut beberapa contoh, boleh jadi "kasus UUPD No. 5 atau 1979" adalah puncak dari, untuk sementara ini, hubungan yang cenderung negatif di antara kedua entitas sosial dan politik tersebut. Puncak ini terjadi ketika hubungan itu telah berubah corak: dari sekedar (dominan) interaksi menjadi seutuhnya (dominan) intervensi. ${ }^{25}$

Sejatinya desa adalah "negara kecil" atau apa yang dimaksud Tet Haar dorps republic, karena sebagai masyarakat hukum desa memiliki semua perangkat suatu negara: teritori, warga, aturan atau hukum (rules atau laws) dan pemerintahan. Dengan ungkapan lain, pemerintahan desa memiliki alat (polisi dan pengadilan desa) dengan mekanisme (aturan atau hukum) untuk menjalankan "hak menggunakan kekerasan" (coercion) di dalam teritori atau wilayah (domain) hukumnya. Wilayah keberlakukan (domain) hukum suatu masyarakat hukum dapat berada suatu teritori yang tetap attinya berlaku bagi setiap orang yang berada di wilayah itu, di manapun ia berada. Pada masyarakat hukum yang relatif, artinya telah memperlakukan teritori sebagai klaim justifikasi (yang tidak boleh dimasuki oleh bukan warga komuniti dan sangsi bagi warga yang melanggarnya), kedua hal ini yang berlaku. Sementara, bagi

${ }^{19}$ Disebut total di sini untuk membedakan bentuk perubahan-perubahan yang sejatinya juga telah pernah dialami desa sepanjang sejarah hidupnya. Bedanya, perbedaan wajah setelah pemberlakuan UUPD No.5/1979 ini jauh lebih berarti ketimbang perubahan-perubahan pada masa-masa sebelumnya itu, Zakaria, op. cit., p. 35.

${ }^{20}$ Lebih jauh baca Zakaria, op. cit., khususnya Bab 2 dan Bab 3.

${ }^{21}$ Bijlmer \& Reurink, op. cit., p. 26.

${ }^{22}$ Sardjono Jatiman (1995), Dari Kampung Menjadi Desa: Studi Sosiologis Perwbahan Pemerintaban Desa di Kabupaten Sambas, Kalimantan Barat. Disertasi Doktoral pada Program Pascasarjana Universitas Indonesia, tidak diterbitkan.

${ }^{23}$ Zakaria, op. cit., p. 36.

${ }^{24}$ Myrna Syafitri (2000), Desa, Institusi Lokal dan Pengelolaan Hutan: Refleksi Kebijakan dan Praktik, Jakarta: Lembaga Studi dan Advokasi Masyarakat.

${ }^{3}$ R.Yando Zakaria, op. cit., p. 285. 
masyarakat hukum yang tingkat perkembangannya masih sangat awal, yang memperlakukan teritori "sekedar basis material" yang dapat dimiliki bersama dengan masyarakat politik lain, wilayah keberlakuan hukumnya bukanlah teritori, melainkan hanya warga masyarakat itu. Batangkali, bedanja yang paling signifikan dengan negara (state) boleh jadi adalah tidak adanya pengakuan kedaulatan oleh negara-negata lain secara internasional. ${ }^{26}$

Studi Shapera, ${ }^{27}$ ahli antropologi, sistem pemetintahan suku-suku primitif di Afrika Selatan menunjukkan bahwa tidak ada perbedaan yang mendasar antara "masyarakat primitif"28 dengan "masyarakat beradab" yang dikenal saat ini. Kedua masyarakat politik itu dibentuk oleh unsur-unsur yang sama, yaitu ikatan kekerabatan dan ikatan territorial. Dengan demikian, Shapera membantah pemikiran-pemikiran antropologi lainnya, seperti Mclver dan bahkan Malinowski, yang menganggap seolaholeh pada "masyarakat primitif" organisasi politiknya hanya dibentuk oleh ikatan kekerabatan semata. ${ }^{29}$ Dengan mengambil beberapa contoh, khususnya di Afrika, Shapera menunjukkan bahwa warga masyarakat dimaksud tidak hanya terikat dalam satu ikatan kekerabatan; mereka bahkan dapat berasal dari suku yang berbeda, yang diikat oleh kesamaan tempat tinggal, wilayah perburuan, dan sebagainya. ${ }^{30}$ Kalaupun ada perbedaan yang hendak dikatakan, hal ini terletak pada lebih pentingnya ikatan kekerabatan pada "masyarakat primitif" dibandingkan pada "masyarakat beradab" atau "masyarakat modern". 31

Berkaitan dengan efektivitas aturan dan pemerintahan, Shapera dalam tulisan yang sama menunjukkan bahwa meskipun relatif "minimal", namun fungsi pemetintahan pada masyarakat-masyarakat politik yang dikaji berjalan efektif: selain menjaga batas-batas territorial dan agresi dari luar, fungsi pemerintahan yang ditemui di semua masyarakat adalah pengorganisasian dan pengarahan untuk hal-hal yang betkaitan dengan kerjasama seluruh warga masyarakat. ${ }^{32}$ Demikian pula dengan aturan dan hukum. Meskipun masyarakat-masyarakat itu tidak memiliki sistem

${ }^{26} \mathrm{Ibid}$.

${ }^{27}$ Shapera (1967), Government and Politics in Tribal Societies, New York: Schoken Books, p. 65.

${ }^{28}$ Yang dimaksud dengan primitif di sini hatus dibaca dalam konteks pencapaian teknologi, bukan dalam dominannya unsut-unsut irasionalitas dalam benak manusia, sebagaimana dimaksud dalam teori psitrologi Jungian. Iebih jauh, lihat Lucy Mair (1962), Primitive Government: $A$ Study of Traditional Political System in Eastern Africa, Bloomington: Indiana University Ptess, p. 10.

${ }^{29}$ Shapera, op. ait., pp. 3-5..

${ }^{30} \mathrm{Di}$ sini, keberlakuan konsep teritorial mungkin hanya sebagai basis material atau sumber ekonomi, dengan implikasi wilayah dimaksud dapat saja dimasuki oleh warga komuniti lainnya. Jadi semacam common-pool resotrtes. Pada komuniti yang lain, yang mungkin diacu para ahli di atas, konsep teritorial telah diberlakukan lebih jauh, yaitu sebagai wilayah kedaulatan komuniti, yang bermakna hukum. Konsekuensinya, warga komuniti lain yang memasuki wilayah ini akan mendapat sanksi, yang umumnya berat.

${ }^{31}$ R.Yando Zakaria op. cit., p. 286. 
pengadilan dan bahkan pemimpin-pemimpin mereka tidak pula mampu menghukum pelanggar aturan, namun kenyataannya masyarakat itu dapat tetap hidup dalam keteraturan. Sebagai "pengganti" mekanisme penggunaan kekerasan (coercion) secara sah sebagai penjamin ketentraman, mereka mengembangkan internal cooperation and external independence" sebagai basis kehidupan bersama mereka. ${ }^{33}$

Dalam pada itu, berbagai sumber menunjukkan bahwa ketegangan antara negara dan komuniti ini terus meningkat seiring dengan berubahnya corak hubungan antara negara dan komuniti dari yang semula lebih dominan interaksi menjadi dominan intervensi. Catatan-catatan sejarah yang tersedia secara pasti juga menunjukkan langkah pergeseran yang cenderung linier: secara pasti bergerak dari arah (dominan) interaksi menuju (dominan) intervensi ini. ${ }^{34}$

Di nusantara, sepanjang sejatahnya, desa telah mengalami interaksi dan intervensi dengan betbagai kebijaksanaan negara. Setidaknya hal ini telah dimulai sejak masa pemerintahan "kerajaan-kerajaan pribumi" (masa prakolonial), negara kolonial (dari VOC hingga pemerintahan Hindia Belanda), hingga setelah munculnya Negara Kesatuan Republik Indonesia sendiri. Disebut interaksi jika hubungan keduanya relatif sejajar atau setidaknya, posisi tawar desa relatif seimbang. Dalam situasi yang demikian negara tidak memaksakan agendanya tanpa menimbulkan resiko yang fatal. Bagi eksistensi negara itu sendiri, karena itu, perhubungan antara keduanya dapat dikatakan betangkat dati kebutuhan pata pihak, bukan hanya salah satu di antara keduanya, sebaliknya, dalam corak hubungan intervensi, selain posisi para pihak tidak sejajar atau tidak seimbang katena posisi tawar salah satu pihak lebih tendah, perhubungan terjadi karena kemauan, bahkan pernaksaan pihak yang

${ }^{32}$ Shapera, op. cit., p. 217.

${ }^{33}$ Ibid., p. 218.

${ }^{3}$ Sebagai ilustrasi, cobalah tengok urutan-urutan peristiwa berikut ini: kisah hubungan negara komuniti pada masa Kerajaan Mataram di Jawa, lihat Soemarsaid Moertono(1985), Negara dan Usaba Bina - Negara di Jawa Masa Lampau, Studi tentang Masa Mataram II, Abad XVI-XTX, Jakarta: Yayasan Obor Indonesia; kisah Hubungan negara - komuniti pada masa Kerajaan Todo - Pongkor di Manggatai, Dami N. Toda (1999), Manggarai Mencari Penceraban Hiostiografi, Ende: Penerbit Nusa Indah; desa dalam sistem pemerintahan Raffles dan desa dalam sistem pemetinthahan Kolonial Belanda pasca Raffles di Jawa (antara lain, periksalah Frans Husken, Magarakat Desa dalam Perubaban Zamon, Sejarah Diferensiasi Sosial di Jawa 1830-1980); nagari di Minangkabau, termasuk diakuinya pengadilan adat (misalnya dalam Keebet von Benda-Beckmann(2000), Goyabnya Tangga Menuju Mufakat, Jakarta: PT.Gramedia Widiasarana Indonesia dan Perwakilan Koninklijk Instituut voor Tall-Land-en Volkenkudende.; dan Franz von Benda-Beckmann (2000), Properti dan Kesinambungan Sosial, Jakarta: PT. Gramedia Widiasarana Indonesia \& Pervakikilan Koninklijk Instituut voor Tall-Land- en Volkenkudende. Pemberiakuan IGO \& IGOB oleh Kolonial Belanda dan desa dalam betbagai UU RI sebelum UU No.5/1979 (misalnya lihat Zakaria, op. at., p. 37. Ternyata ini bukan fenomena khas Indonesia, tetapi juga negara lain, seperti Cina, I. Wibowo(2000), Negara dan Masjarakat, Berkaca dar Pengalaman Republik Rakjat Cina. Jakarta: Gramedia Pustaka Utama dan Pusat Studi Cina, p. 48. 
kuat. Argumentasi bahwa "karena kebutuhan pihak (yang lebih) lemah, yang belum mampu medefinisikann kebutuhannya sendiri" harus ditafsirkan sebagai argumentasi hegemoni pihak yang kuat, untuk menjustifikasi campur tangannya. ${ }^{35}$

\section{Otonomi antara Hak Asal dan Hak Berian}

Jika begitu keadaannya masih adakah ruang untuk membalikkan bandul dati dominan intervensi menjadi dominan interaksi? Sebelum menjawab pertanyaan ini petlu dilakukan telaah tentang bagaimana kontitusi Indonesia mengatur keberadaan komuniti (baca: Desa) ini. Pada Undang-Unadang Dasar Negata Republik Indonesia tahun 1945 (berita republik Indonesia, II, 7, hal 45-48; Penjelasan halaman 5156 (khususnya bab VI, yang berjudul pemerintahan daerah, terdapat pasal 18 yang berbunyi " pembagian daerah Indonesia atas daerah besar dan kecil dengan bentuk susunan pemerintahannya ditetapkan dengan UU, dengan memandang dan mengingat dasat pemusyawaratan dalam sistem pemerintahan negara, dan hak-hak asal-usul dalam daerah-daerah yang bersifat istimewa. ${ }^{36}$

Pada penjelasan Undang-Undang Dasar Negara Republik Indonesia tahun 1945, khususnya dalam bagian penjelasan pasal demi pasal, untuk bab VI, pasal 18 ini diberikan catatan bahwa negara Indonesia itu suatu "eenbeistaat", maka Indonesia tidak akan mempunyai daerah di dalam lingkungannya yang bersifat "Stat" juga. Daetah Indonesia akan dibagi dalam daerah propinsi, dan daerah propinsi akan dibagi pula dalam daetah yang Iebih kecil. Daerah-daerah yang bersifat otonom (streek dan locale rechtsgemeenschappeen) atau bersifat daerah administrasi belaka, semuanya menurut aturan yang akan ditetapkan dengan Undang-Undang. Di daerahdaerah yang bersifat otonom akan diadakan badan perwakilan daerah, oleh karena di daerahpun pemerintahan akan bersendi atas dasar permusyawaratan. ${ }^{37}$

Dalam teritorial negara Indonesia terdapat lebih kurang 250 "Zelfbesturende landschappen", seperti desa di Jawa dan Bali, nagari di Minangkabau, dusun dan marga di Palembang dan sebagainya. Daerah-daerah ini mempunyai susunan asli dan oleh karenanya dapat dianggap sebagai daerah yang bersifat istimewa. ${ }^{38}$

Negara Republik Indonesia menghormati kedudukan daerah-daerah istimewa tersebut dan segala peraturan negara yang mengenai daerah itu akan mengingat hak-hak asal usul daerah tersebut. Jika dilihat secara mendalam makna pengaturan sebagaimana tercantum dalam pasal 18 UUD 45 berikut penjelasannya, dapat

${ }^{35}$ R.Yando Zakaria, op. cit., p. 287.

${ }^{36}$ Kutipan-kutipan tentang Undang-Undang Dasar 1945 bersumber dari buku yang berjudul (1995), Tiga Undang-Undang Dasar: UUD RI 1945, Konstifusi RIS, UUD Sementara RI, yang dihimpun dan diterbitkan oleh Penerbit Ghalia Indonesia.

${ }^{37}$ R.Yando Zakatia, op. cit., p. 288.

${ }^{38}$ Tbid. 
dikatakan bahwa esensi dari pasal 18 UUD 45 adalah adanya pengakuan negara tethadap apa yang disebut dengan "otonomi desa". dewasa ini. Lebih dari itu, dengan menyebutkan desa sebagai susunan asli yang memiliki hak asal-usul, maka menurut UUD 45 hanya desa yang dipastikan memiliki otonomi. Sedangkan "daerah daerah besar dan kecil lainnya", semacam propinsi, kabupaten, atau kecamatan yang dikenal dalam sistem pemerintahan nasional sekarang ini, dapat saja bersifat otonom atau administrasi belaka. Apakah masing-masing "daerah besar dan kecil" itu diberi status otonom atau administratif tergantung "kebutuhan", perimbangan kekuatan politik pusat dan daerah, sebagaimana dituangkan dalam Undang-Undang. ${ }^{39}$

Selain itu, dengan menyebut desa sebagai susunan asli maka desa adalah "persekutuan sosial, ekonomi, politik, dan budaya" yang berbeda hakekatnya dengan sebuah "persekutuan administratif di atas sebagaimana yang dimaksud dengan pemeritahan desa" dalam berbagai peraturan perundangan yang ada. Karenanya, sebagai susunan asli, sering desa mewujudkan diri sebagai apa yang disebut Ter Haar sebagai dorps republic atau "negara kecil", sebagai lawan kata "negata besar yang mengacu pada suatu tatanan modern state. ${ }^{40}$

Berkaitan dengan adanya pengakuan atas otonomi desa ini, dalam wacana politik hukum dikenal adanya dua macam konsep hak berdasatkan asal-usulnya. Masing-masing hak berbeda satu sama lainnya, pertoma, yaitu hak bersifat berian (hak berian), dan kedua adalah hak yang merupakan bawaan yang melekat pada sejarah asal usul unit yang memiliki otonomi itu (hak bawaan). Dengan menggunakan dua perbedaan ini maka otonomi daerah yang dibicarakan banyak orang dewasa ini adalah otonomi yang bersifat berian ini. Karena itu, wacananya bergeser dari hak menjadi wewenang (autbority). Kewenangan selalu merupakar pemberian, yang selalu harus dipertanggungjawabkan. Selain itu, konsep urusan rumah tangga daetah hilang diganti dengan kepentingan masyarakat. Dengan demikian, otonomi daerah merupakan kewenangan pemerintahan daerah untuk mengatut kepentingan masyarakat di daerah. ${ }^{41}$

Berbeda dengan hak yang bersifat berian, adalah hak yang bersifat bawaan, yang telah tumbuh berkembang dan terpelihara oleh suatu kelembagaan (institution)

${ }^{39}$ Telah terdapat sekurang-kurangnya 7 peraturan perundangan yang mengatur masalah ini. Pada masing-masing peraturan perundangan itu terdapat kecenderungan yang berbeda satu sama lainnya. Tentang hal ini, baca Bhenyamin Hoessen (1993), Berbagai Faktor yang Menpengarubi Besarnya Otonomi Daerab Tingkat II, Suatu Kajian Desentralisasi dan Otonomi Datrah dari Segi Ilmu Administrasi Negara. Disertasi untuk Gelat Doktor pada Program Pascsarjana Universitas Indonesia dan Desentralisasi dan Otonomi Daèah di Negaia Kesatuan Republik Indonesia, Naskah Pidato Pengukuhan Guru Bésar dalam Ilmu Adminitrasi Negata pada Fakuiltas Ilmu Sosial dan Ilmu Politik Universitas Indonesia (1995), baca juga Zakaria, op. cit., pp. 33-87.

${ }^{40}$ R.Yando Zakaria, op. cit., p. 289.

${ }^{41}$ Ibid. 
yang mengurus urusan rumah tangganya sendiri. Dalam UUD 45 konsep hak bawaan inilah yang melekat pada "daetah yang betsifat istimewa "yang memiliki" hak-hak asal usul". Karena itu, berbeda dengan pemerintah daerah, desa dengan otonomi desa yang muncul sebagai akibat diakuinya hak asal-usul dan katenanya betsifat istimewa itu, memiliki hak bawaan dati desa sebagai susunan asli itu setidaknya mencakup hak atas wilayah (yang kemudian disebut bak ulayat), ${ }^{42}$ sistem pengorganisasian sosial yang ada di wilayah yang bersangkutan "sistem kepemimpinan termasuk di dalamnya aturan-aturan dan mekanisme pembuatan aturan di wilayah yang bersangkutan yang mengatur seluruh warga (asli atau pendatang) yang tercakup di wilayah desa yang bersangkutan. ${ }^{43}$

Sebenatnya inilah pangkal dari ketegangan yang nyaris abadi antara negata di satu pihak dengan masyarakat (baca: komuniti dan desa) di pihak lain. Ketegangan ini menyangkut hal bagaimana negara merealisasikan otonomi desa yang secara politik dan hukum terakomodasi dalam peraturan perundangan yang ada khususnya yang menyangkut hak atas penguasaan atas wilayah desa, aturan-aturan, dan sistem pengorganisasian hidup bersama di wilayah itu. ${ }^{44}$

\section{Pemulihan Kebidupan Komuniti}

Berangkat dari kebutuhan orang kampung sebagaimana telah dicontohkan di atas, melalui pengakuan terhadap hak asal-usul, yang diperlukan adalah undangundang atau peraturan daerah yang mengatur tentang penyelenggaraan pemerintahan nasional di desa (atau disebut dengan nama lain) dalam wilayah administrasi RI dan atau pada daerah kabupaten atau kota. ${ }^{45}$

Setidaknya undang-undang atau peraturan daerah dimaksud mengatur ketentuan-ketentuan tentang adanya "otonomi" pada "susunan-susunan asli" sebagaimana dimaksud oleh UUD 1945 Pasal 18 (seperti desa, nagari, marga, dan lain-lain yang kesemuanya dicetak miting yang betbeda dengan desa cetak biasa); Aturan tentang definisi Desa di wilayah dimaksud; berikut dengan mekanismemekanisme dengan pengembangannya; Ketentuan-ketentuan tentang desa di wilayah yang dimaksud sebagai penyelenggara pemerintahan nasional di wilayah desa dimaksud (dalam hal perda adalah sebagaimana diatur dalam UU No. 22/99 dan UU No.32/2004). Dengan cara ini, dualisme institusi di desa tidak terjadi. Desa adalah (sistem) pemerintahan desa itu senditi penyelenggaraan pemerintahan di tingkat desa, dengan demikian, hanyalah merupakan salah satu tugas dari institusi

${ }^{42}$ Karenanya hak ulayat lebih mengacu pada pengertian wilayah kedaulatan dan bukan hak garap bersama, Zakaria, op. iti., pp. 241-258.

${ }^{43}$ R.Yando Zakaria (2002), op. cit., p. 289.

HIbid.

${ }^{45}$ Ibid., p. 296. 
atau organisasi desa itu senditi; Ketentuan-ketentuan tentang corak hubungan desa dengan unit-unit pemerintahan nasional yang lainnya, seperti kecamatan, kabupaten, dan propinsi; Ketentuan-ketentuan tentang aturan-aturan peralihan. Dalam bagian ini penting untuk dijelaskan adanya perintah pada negara, entah nasional ataupun daerah, untuk mengalokasikan dana negara bagi upaya-upaya perbaikan kerusakankerusakan sosial dan ekologasi sebagai akibat kekelituan penerapan kebijakan sebelumnya, dan juga untuk menetapkan pilihan-pilihan bentuk pemerintahan desa yang akan ditempuh pada masa-masa yang akan datang. ${ }^{46}$

Agar Perda "Pemerintahan Desa" yang sesuai dengan "adat setempat" memiliki cantolan hukum yang lebih kuat (UU No. 22/1999 dan UU No.32/200477 hanya UU tentang pemerintahan daerah karenanya sulit untuk menerapkan otonomi asli sepenuhnya), maka, ditingkat nasional, diperlukan pula UU tentang pengakuan "asalusul susunan asli, atau komuniti, atau masyarakat adat" itu sendiri; ${ }^{48}$

${ }^{46}$ Ibid., p. 293.

${ }^{47}$ UU No 32/2004 dapat membunuh demokrasi di desa. Eksistensi BPD yang menurut UU No 22/1999 merupakan kependekan dari Badan Perwakilan Desa, dalam UU No 32/2004 memang terlihat mengalami transformasi eksistensi dan fungsi yang cukup signifikan. UU No 32/2004 telah mengubah format kedudukan BPD menjadi "sekadar" Badan Permusyawaratan Desa, yang seharusnya tidak lagi disingkat menjadi $B P D$, tetapi Bamusdes. Substansi kewenangan lembaga rakyat desa itu juga telah mengalami reduksi. Fungsi Bamusdes menurut Pasal 209 UU No 32/2004 hanya meliputi: (1) Menetapkan peraturan desa bersama Kepala Desa dan (2). Menampung dan menyalurkan aspirasi masyarakat. Kewenangan tersebut lebih sempit bila dibandingkan dengan kewenangan normatif BPD, yang sebelumnya pemah diatur dalam Pasal 104 UU No 22/1999 yang meliputi: (1) Mengayomi adat istiadat; (2). Membuat peraturan desa; (3): Melakukan pengawasan terhadap penyelenggaraan Pemerintah Desa. Apabila kewenangan Bamusdes dalam UU No $32 / 2004$ dibandingkan dengan kewenangan BPD dalam UU No $22 / 1999$, terlihat ada 2 (dua) macam kewenangan yang (sengaja) dihilangkan dari lembaga rakyat desa tersebut, yaitu kewenangan untuk mengayomi adat istiadat dan melakukan pengawasan terhadap penyelenggaraan pemerintah desa. Dua macam kewenangan yang hilang tersebut, hakikatnya merupakan kewenangan esensial dari sebuah parlemen desa. Fungsi hakiki suatu parlemen dalam teori demokrasi modem adalah untuk menjalankan pengawasan terhadap eksekutif, guna mencegah terjadinya kesewenangwernangan eksekutif dan dalam kerangka membangun sistem checks and balances dalam penyelenggaraan pemerintahan. UU No 32/2004 sangat menekankan prinsip posver sharing antata jenis kewenangan pemerintahan, yaitu antara perimbangan kewenangan dekonsentrasi dengan kewenangan desentralisasi. Hal tersebut terlihat dalam pengaturan pembagian kewenangan antan Pemerintahan Pusat dengan Daerah dan antara kewenangan Pemerintahan Propinsi dengan Kabupater/kota, yang sebelumnya terlihat masih bias pengaturannya dalam UU No 22/1999. UU No 22/1999 oleh banyak kalangan dinilai telah memutuskan saluran administratif dan kootdinatif antata Pusat dan Daerah, yang berekses secara politis tampilnya banyak "raja-raja kecil" yang mengelola daerahnya ibarat suatu negara bagian dalam sistem federal. Hal itu disebabkan, UU No 22/1999 sangat multiin terpretatif dalam perumusan aturan mengenai kewenangan Daerah, dan mẹmbuka tuảng diskresi yang terlampau longgar bagi penyelenggara kekuașaan di Daerah.

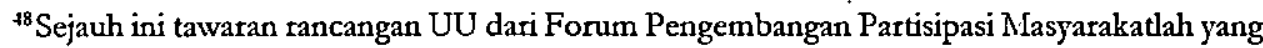
mendekati konsepsi yang dikemukakan di atas, Forum Pengembangan Partisipasi Masyarakat, Usulan Naskah Akademik tentang Perubahan Undang-Undang Republik Indonesia No. 22 Tahun 1999 yang 
Terkait dengan persoalan di atas, yang lebih pokok adalah, mengingat kebijakankebijakan lama, ataupun perkembangan sosial, ekonomi, politik dan budaya lainnya, telah merubah kehidupan di desa, perda dimaksud juga membuka peluang bagi terakomodasinya keberagaman desa di daerah yang bersangkutan; termasuk terakomodasinya keberagaman pilihan bentuk "pemerintahan desa" yang sesuai dengan aspirasi konstituennya, apakah akan dilaksanakan secara "adat" atau "secara formal"; seperti yang terjadi dan berdampak baik bagi kehidupan masyarakat di daerah yang bersangkutan - di negara bagian Oaxaca Mexico). ${ }^{49}$

Dalam situasi yang telah berubah itu ada baiknya juga jika komuniti diberi kesempatan untuk memilih sistem "Pemerintahan Desa" yang paling cocok bagi kehidupan masyarakat itu pada hari ini. Pilihan itu dapat saja menyangkut tetap menjalankan sistem "pemerintahan fotmal" ataupun kembali secara adat yang pernah dikenal komuniti itu sebelumnya. Adanya ruang pilihan ini pada hakekatnya merupakan ekspresi dari pengakuan atas adanya keberagaman di tingkat komuniti itu sendiri. Sebuah kebijakan baru yang tidak membuka kemungkinan ini sama saja dengan memindahkan penyakit sentralisasi semula di tingkat nasional menjadi sentralisasi di tingkat lokal (daerah)..$^{50}$

\section{E. Penutup}

Keberlangsungan negara bangsa Indonesia akan ditentukan oleh bagaimana negata ini mampu menata ulang hubungannya dengan komuniti. Tidak akan ada negara yang akan bertahan lama tanpa tindakan-tindakan politik yang represif jika tidak didukung oleh komuniti yang sehat dan hidup. Sementara itu, tindakan-tindakan politik yang represif hanya akan mengantar negara bangsa ini pada posisi "sementara" dan "tidak mantap" begitu pula, masyarakat sipil sejatinya tidak akan tercipta tanpa kehadiran komuniti-komuniti yang sehat dan hidup itu. ${ }^{51}$

berkaitan dengan Desa, Jakarta Agustus 2001. Hanya saja dalam beberapa hal, usulan tersebut masih juga terjebak untuk mengatur, dan dapat berakibat melemahkan, pengakuan otonomi desa. Ambil contoh tentang bagian Pokok-pokok Materi Muatan yang diatur d), d.1, dan d.2. Pengakuan atas otonomi desa tidak mesti bermuara pada pembentukan Pemerintah Desa tetapi cukup ada bagian yang mengurusi masalah pernerintahan nasional di desa yang otonom itu. Dalam banyak kasus yang lain, temasuk proses-proses yang mendapat intervensi dari kalangan omop, peluang perbaikan yang ada hanya bermuara sekedar mengganti nama desa dengan nama yang cocok di daerah yang bersangkutan. Bahkan dalam perda-perda tentang nagari di Sumatera Barat, perda tentang Lembang di.Tanah Toraja, dan perda tentang kampong di Sangau, Kalbat, yang difasilitasi melalui proses-proses pertemuan di tingkat kampong sekalipun. Hal yang demikian terjadi, terutama terletak pada kelemahan atau belum cleanya pengertian tentang otonomi desa itu sendiri, R.Yando Zakaria, Ibid., p. 297.

${ }^{49}$ Sekedar menyebut satu dokumentasi, periksalah Noer Fauzi (et al) (2000), Trampas Muchas Politicas: Catalan Perjalanon ke Meksika, Jakarta: Ford Foundation. Tidak diterbitkan.

${ }^{50} \mathrm{R}$.Yando Zakatia (2002), op. cit., p. 297.

${ }^{51}$ Ibid. 
Sejatinya negara memang harus selalu dalam posisi "sementara", "tidak mantap", dan "tidak final" karena, seperti dikatakan Anderson, negara adalah "suatu kesatuan masyarakat yang dibayangkan ada". ${ }^{52}$ Hanya saja, core kehadiran negara itu harus dirubah dari yang berpusat pada negara itu sendiri pada komuniti. Dengan meletakkan core kehadiran negara pada komuniti sekaligus akan menghindarkan kita dari makna saktal negara yang dalam sejarahnya telah menyebabkan persimbahan darah. Dengan posisi yang demikian ini, negara tak lebih sebagai suatu sistem administrasi kehidupan bersama yang lentur, adaptif, sama sekali tidak sakral, sehingga tidak perlu ditangisi, apalagi berkorban nyawa, jika ia memang harus berubah areal cakupan, sesuai tuntunan zamannya. ${ }^{53}$

Oleh karena itu, sama sekali tidak ada alasan yang kuat untuk menghawatitkan pemberian otonomi penuh tersebut kepada komuniti. Sebaliknya, bahwa pengingkaran terhadap hak-hak otonomi komuniti inilah yang justru menjadi kayu bakar bagi gerakan-gerakan yang mengarah pada disintegrasi Nasional. ${ }^{54}$

Yang ingin dikatakan adalah, entitas suatu negara hanya relevan dalam satu jangka waktu tertentu saja. Ia bisa menghianati rasa keadilan komuniti, dan bahkan bisa saja menindas peri kemanusiaan, dalam konteks waktu yang lainnya. Karenanya, negara, terlebih lagi negara bangsa, sebagai suatu yang dimajikan (akan) ada itu, haruslah diletakkan sebagai satu sasaran antata, bersifat sementara, tidak mantap, dan sama sekali tidak sakral. Hanya dengan begitu kita dapat lepas dari paradokparadoks kehadiran negara dan "sesat pikir" tentang (konsep) negara itu sendiri. ${ }^{55}$

\section{DAFTAR PUSTAKA}

Anderson, Benedict (2001), Imagined Communities Komunitas-komunitas Terbayang, terjemahan Omi Intan Naomi dari Imagined Communities: Reflections on the Origin and Spread of Nationalism, Yogyakarta: Pustaka Pelajar dan INSIST Press.

Beckmann, Franz von Benda (2000), Properti dan Kesinambungan Sosial, Jakarta: PT. Gramedia Widiasarana Indonesia \& Perwakilan Koninklijk Instituut voor TallLand- en Volkenkudende.

(2000), Goyabnya Tangga Menuju Mufakat, Jakarta: PT.Gramedia Widiasarana Indonesia dan Perwakilan Koninklijk Instituut voor Tall-Land- en Volkenkudende.

${ }^{52}$ Benedict Anderson (2001), "Imagined Communities Komunitas-komunitas Terbayang" terjemahan Omi Intan Naomi dari Imagined Communities: Reflections on the Origin and Spread of Nationalism, Yogyakarta: Pustaka Pelajat dan INSIST Press, p. 46.

${ }^{53}$ R. Yando Zakatia (2002), op. cit., pp. 297-298.

5 Tentang hal int baca Zakaria, op. cit., p. 35.

${ }^{55}$ R. Yando Zakaria (2002), op. cit., p. 298. 
Bijlmer, Joep \& Martin Reurink (1988), “Kepemimpinana Lokal di Lingkungan Urban Jawa: dari Ideologi ke Realitas" dalam Philip Quartes van Ufford, (ed.), Kepemimpinana Lokal dan Implementasi Program, Jakarta: PT. Gramedia.

Dami N. Toda (1999), Manggarai Mencari Pencerahan Hiostiografi, Ende: Penerbit Nusa Indah.

Evers, Pieter J. (2000), Resourceful Villagers, Power-less Communities: Rural Village Government Indonesia, Jakarta: Working Draft Level Institution Study/Indonesia, a World Bank/Bappenas Research Project, January.

(1999), Village Governments and Their Coomunities, Jakarta: World Bank/ Bappenas, Local Level Institution Study.

Forum Pengembangan Partisipasi Masyarakat (2001); Usulan Naskab Akademik tentang Perubaban Undang-Undang Republik Indonesia No. 22 Tabun 1999 yang berkaitan dengan Desa, Jakarta Agustus.

Grootaert, Christiaan (1999), Sosial Capital, Housebold Welfare and Poverty in Indonesia, Washington D.C: World Bank, Social Development Departemen.

(1999), Local Institution Service Celiveruy in Indonesia, Washington D.C: World Bank, Social Development Departemen.

Hoessen, Bhenyamin (1993), Berbagai Faktor Yang Memepengarubi Besarnya Otonomi Daerab Tingkat II, Suatu Kajian Desentralisasi dan Otonomi Daerah dari Segi Ilmu Administrasi Negara, Disettasi untuk Gelar Doktor pada Program Pascsarjana Univetsitas Indonesia.

(1995), Desentralisasi dan Otonomi Daerab di Negara Kesatuan Republik Indonesia, Naskah Pidato Pengukuhan Guru Besar dalam Ilmu Adminitrasi Negara pada Fakultas Ilmu Sosial dan Ilmu Politik Universitas Indonesia.

Husken, Frans (tt), Masyarakat Desa dalam Perubaban Zaman, Sejarab Diferensiasi Sosial di Jawa 1830-1980); Nagari di Minangkabau.

I. Wibowo (2000), Negara dan Masyarakat, Bekaca dari Pengalaman Republik Rakyat Cina, Jakarta: Gramedia Pustaka Utama dan Pusat Studi Cina.

Kamala Chandrakirana (1999), Local Capacity and Its Implications for Development: The Case of Indonesia, Jakarta: World Bank/Bappenas, Local Level Institutions Study.

Koentjaraningrat (1979), Pengantar Ilmu Antropologi, Jakarta: Aksara baru. (1990), Sejarah Teori Antropologi II, Jakarta: UI Press.

Mait, Lucy (1962), Primitive Government: A Study of Traditional Political System in Eastern Africa, Bloomington: Indiana University Press.

Musa Asy'arie (2005), NKRI, Budaya Politik dan Pendidikan, Yogyakarta: LESFI

Myrna Syafitri (2000), Desa, Institusi Lokal dan Pengelolaan Hutan: Refleksi. Kebijakan dan Praktik, Jakarta: Lembaga Studi dan Advokasi Masyarakat.

Noer Fauzi (et,al) (2000), Trampas Muchas Politicas: Catatan Perjalanan ke Meksiko, 
Jakarta: Ford Foundation. Tidak diterbitkan.

Penerbit Ghalia Indonesia (1995), Tiga Undang-Undang Dasar: UUD RI 1945, Konstitusi RIS, UUD Sementara RI, Jakarta: Penerbit Ghalia Indonesia.

R. Yando Zakaria (1997), "Penegakan Hak-Hak Masyarakat Adat'Sebagai sebuah Krisis Integrasi Nasional di Masa Depan" makalah yang disampaikan pada "Widyakarya Nasional Antropologi dan Pembangunan" diselenggarakan oleh Direktorat Jenderal Kebudayaan DEPDIKBUD dan Panitia Kongres Asosiasi Antropologi Indonesia, 26-27 Agustus.

(2000), Abieh Tandeh, Masyarakat Desa di Bawab Orde Baru, Jakarta: Lembaga Studi dan Advokasi Masyarakat.

(2002), "Pemulihan Kehidupan Desa dan.UU No. 22 Tahun 1999" dalam UNISIA Jurnal Ilmu-Ilmu Sosial, Yogyakarta: Universitas Islam Indonesia.

(2004), Merebut Negara Beberapa Cataton Reflektif tentang Upaya-upaya Pengakuan, Pengembalian dan Pemuliban Otonomi Desa, Yogyakarta: Lapera Pustaka Utama bekerja sama dengan Karsa.

Riawan Tjandra (2006), "Demokrasi Desa" dalam Harian Kedaulatan Rakyat, Rabu 8 Februari.

Sardjono Jatiman (1995), Dari Kampung Menjadi Desa: Studi Sosiologis Perubahan

Pemerintaban Desa di di Kabupaten Sambas, Kalimantan Barat. Disertasi Doktoral pada Program Pascasatjana Universitas Indonesia, tidak diterbitkan.

Shapera, I. (1967), Government and Politics in Tribal Societies, New York: Schoken Books.

Soemarsaid Moertono (1985), Negara dan Usaba Bina-Negara di Jawa Masa Lampau, Studi tentang Masa Mataram II, Abad XVI-XIX, Jakarta: Yayasan Obor Indonesia.

Soetandjo Wignjosoebroto (1997), "Komunitas Lokal Versus Negara Bangsa: Perbedaan Persepsi dan Konsepsi tentang Makna Lingkungan" makalah yang dipresentasikan dalam diskusi bertemakan 'Hubungan Negara-Masyarakat dalam Pengelolaan Lingkungan" yang diselenggarakan oleh Yayasan Lembaga Bantuan Hukum Indonesia, Jakarta: tanggal 3 Juli 1997.

Uphoff (1996), Learning From Gai Oya, Possibilities for Participatory Development and Post Newtonian Social Science, London: Intermediate Technology Publications Ltd. 